\title{
PENDIDIKAN SALAT TERHADAP ANAK DALAM PERSPEKTIF HADIS
}

\author{
Jumasni \\ Ilmu Hadis, Pascasarjana UIN Alauddin Makassar, Samata-Gowa \\ masnhyannhy12@gmail.com
}

\begin{abstract}
Abstrak: Hasil penelitian ini menunjukan bahwa perintah salat terhadap anak terdapat 13 jalur hadis secara keseluruhan. Peneliti membatasi pada kitab sembilan yaitu 7 riwayat, melalui 2 sahabat dan tabiin dari 4 mukharrij.Kualitas hadis tentang perintah salat terhadap anak dinilai sahih, karena telah memenuhi kriteria syarat-syarat hadis sahih sanad dan matan. Berdasarkanpenelitian analisis hasil wawancara, bahwa pendidik dalam hal guru yang mengajarkan siswanya salat telah berdasarkan apa yang ada dalam hadis membiasakan atau memberikan pelajaran yang terkait hal salat kepada siswa-siswinya khusus kelas satu sampai tiga. Ketika sudah kelas empat yang umurnya menghampiri sepuluh tahun, bagi siswa-siswi yang melanggar aturan. Maka, diberikan hukuman atau sangsi berupa menyuruh menghafal surah-surah pendek dan memungut sampah.
\end{abstract}

Kata Kunci: Pendidikan Anak; Hadis

\section{PENDAHULUAN}

Islam sebagai agama yang universal, ajarannya meliputi segala aspek kehidupan manusia namun bukan hanya aspek yang menyentuh hubungannya kepada Allah melainkan juga menyentuh hubungannya dengan manusia. Hal ini dapat dilihat dalam perkembangan ilmu pengetahuan yang telah terjadi islamisasi terhadap ilmu-ilmu, lahirlah ilmu teologi Islam sosiologi agama ekonomi Islam dan lain sebagainya. Salah satu aspek ajaran Islam yang paling diperhatikan adalah masalah pendidikan.

Seorang muslim yang taat tentu akan termotivasi untuk melaksanakan ibadah yang diperintahkan Allah swt., dan berusaha untuk mengajarkannya kepada anak-anaknya dalam bentuk latihan dan pembiasaan. Terbukti dalam firman Allah swt. QS Ṭāhā/20: 132.

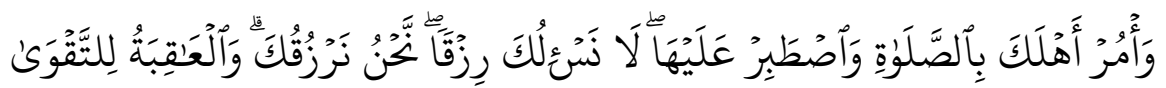

Terjemahnya:

"Dan perintahkanlah keluargamu melaksanakan salat dan sabar dalam mengerjakannya. Kami tidak meminta rezeki kepadamu, Kamilah yang memberi rezeki kepadamu. Dan akibat (yang baik di akhirat) adalah bagi orang yang bertakwa."

Ayat di atas menjelaskan sabar terhadap kesungguhan menjaga salat dengan ditunjukan melalui perbuatan. Bukan hanya berlaku untuk diri seseorang tetapi juga untuk keluarganya. Artinya, pembiasaan mendirikan salat dalam sebuah keluarga bukan sekadar sabar dalam maknanya pasif, membutuhkan 
ketelatenan yaitu upaya terus-menerus dengan berbagai cara. Yang terkadang bisa dilakukan dengan sikap persuasif, namun dalam situasi tertentu diperlukan pula tindakan tegas. Ini dimaksudkan agar seluruh anggota keluarga benar-benar menegakan salat.

Berkaitan dengan pendidikan anak, khususnya dalam lingkungan keluarga, Nabi saw., memberikan contoh yang baik dalam mendidik anak yaitu pertama, melalui pembiasaan. Pengasuhan dan pendidikan di dalam lingkungan keluarga, lebih diarahkan penanaman nilai-nilai moral keagamaan, pembentukan sikap dan perilaku yang diperlukan agar anak-anak dapat mengembangkan dirinya secara optimal. Penanaman nilai-nilai moral agama ada baiknya diawali dengan pengenalan simbol-simbol agama, dalam hal ini tata cara salat, membaca al-Qur'an, doa-doa dan sebagainya. Kedua, pendidikan melalui keteladanan. Anak-anak khususnya pada usia dini selalu meniru apa yang dilakukan orang sekitarnya, untuk menanamkan nilai agama termasuk pengamalan agama, seperti salat. Jika orang tua menginginkan anak-anak mereka melaksanakan salat, tentu orang tua terlebih dahulu melaksanakan salat.

Mengenai hadis-hadis pendidikan salat pada anak yang meliputi usia anak, yang diperintahkan untuk salat dan sanksi bagi yang meninggalkannya serta hadis-hadis tentang sanksi pukulan, setelah ditelusuri telah didapatkan dalam berbagai kitab. Salah satu diantara hadis tentang sanksi terhadap anak yang melalaikan salat bila sudah berumur sepuluh tahun, yaitu sebagai berikut:

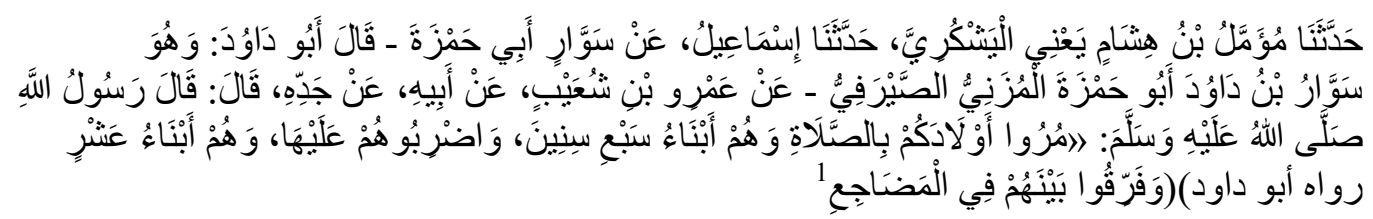

Artinya:

"Telah menceritakan kepada kami Muammal bin Hisyam Al-Yasykuri telah menceritakan kepada kami Isma'il dari Sawwar Abu Hamzah berkata Abu Dawud; Dia adalah Sawwar bin Dawud Abu Hamzah AlMuzani Ash-Shairafi dari Amru bin Syu'aib dari Ayahnya dari Kakeknya dia berkata; Rasulullah shallallahu 'alaihi wasallam bersabda: Perintahkanlah anak-anak kalian untuk melaksanakan shalat apabila sudah mencapai umur tujuh tahun, dan apabila sudah mencapai umur sepuluh tahun maka pukullah dia apabila tidak melaksanakannya, dan pisahkanlah mereka dalam tempat tidurnya."

Hadis tersebut menurut penulis, tidak benar-benar memerintahkan seorang anak kecil untuk salat, sebab dalam usia tujuh tahun seorang anak belum layak mendapatkan beban agama (mencapai batas taklif). Maksudnya, jika ia tidak melaksanakan salat maka ia tidak berdosa. Oleh karena itu, hadis tersebut

${ }^{1}$ Abū Dāud Sulaimān bin al-Asy'as bin Ishāq bin Basyīi bin Syaddād bin 'Amr al-Azdi al-Sijistāni, Sunan Abū Dāud, h. 133. 
harus dipahami dalam konteks pendidikan, bahwa menanamkan kebiasaan salat dan juga nilai-nilai luhur lainnya tidak mudah. Harus mulai ditanamkan dan diajarkan sejak usia dini, sehingga untuk itu dibutuhkan kesabaran.

Hadis ini pula usia anak mulai diperintahkan untuk salat, karena pada usia inilah anak sudah mampu menerima perintah atau sudah paham menerima perintah yang disebut dengan istilah mumayyiz, usia kritis atau cerdas. Demikian juga pada usia inilah anak didik diperkirakan sudah bisa belajar salat dengan baik, sudah mulai mengenal bacaan dan gerakan-gerakan salat dengan baik. Kalau usia sebelumnya anak hanya ikut-ikutan, akan tetapi pada usia ini sudah mulai mampu belajar salat dengan baik. Konsekuensi anak yang telah mampu belajar salat dengan baik berarti pula ia telah menerima hukuman jika meninggalkannya.

\section{PEMBAHASAN}

\section{A. Pendidikan Salat}

Pendidikan berasal dari kata dasar didik, yang berarti memelihara dan memberi latihan (ajaran, tuntunan, pimpinan) mengenai akhlak dan kecerdasan pikiran $^{2}$. Sedangkan pendidikan berarti proses pengubahan sikap dan tata laku seseorang atau kelompok orang dalam usaha mendewasakan manusia melalui upaya pengajaran dan pelatihan yang meliputi cara, proses, dan perbuatan mendidik.

Dalam proses pendidikan ada beberapa komponen yang saling berintegrasi, yaitu pendidik, peserta didik, tujuan pendidikan, materi pendidikan serta metode pendidikan. Yaitu sebagai berikut:

\section{Pendidik}

Penamaan pendidik dalam lingkungan keluarga adalah orang tua dari anak-anak yang biasanya menyebut dengan sebutan ayah dan ibu. Dalam lingkungan masyarakat penamaan pendidik disebut istilah tutor, fasilitator, at au instruktur. Pada lingkungan sekolah disebut guru.

Undang-Undang Republik Indonesia nomor 20 tahun 2003 tentang Sistem Pendidikan Nasional bab I, pasal I, ayat 6 menyebutkan bahwa pendidik sebagai tenaga kependidikan yang berklasifikasi sebagai guru, dosen, konselor, tutor, fasilitator, ataupun sebutan lainnya berpartisispasi dalam menyelenggarakan pendidikan. ${ }^{3}$

${ }^{2}$ Tim Pustaka Phoenix, Kamus Besar Bahasa Indonesia, Edisi Baru, h. 187.

${ }^{3}$ Republik Indonesia, "Undang-Undang RI Nomor 20 Tahun 2003 tentang Sistem Pendidikan Nasional" (Cet. II; Bandung: Citra Umbara, 2010), h. 2-3. Pendidikan dilakukan melalui tiga kegiatan yakni membimbing, mengajar, dan melatih (ayat 1 Pasal 1 dari UU RI No. 2/1989). Ketiga kegiatan tersebut memiliki tujuan yang berbeda yakni, pertama membimbing, untuk pemantapan jati diri dan pribadi dari segi-segi perilaku umum (aspek pembudayaan), kedua mengajar, terutama berkaitan dengan penguasaan ilmu pengetahuan, dan ketiga melatih, untuk 
Pengertian pendidikan dalam tinjauan Islam, ada beberapa konteks dalam bahasa Arab yaitu menggunakan term al-tarbiyah, al-ta'lim dan alta'dib. Ketiga istilah tersebut memberikan kesan antara satu istilah dengan istilah lainnya. Adapun penjelasannya yaitu sebagai berikut:

a) Tarbiyah

Kata tarbiyah mempunyai beberapa makna pertama, berasal dari kata raba yarbū yang berarti bertambah dan berkembang. Sehingga tarbiyah dalam arti bahasa dapat berarti proses menumbuhkan dan mengembangkan apa yang ada pada diri peserta didik, baik secara fisik, psikis, maupun spiritual. Kedua, kata tarbiyah dari kata rabba yurabbi berarti mengasuh, mendidik .

b) Ta' $\overline{\lim }$

Ta'lim berasal dari kata Kemudian lafal tersebut berubah menjadi (wazan sulāisi mazid ) علّم - يعلم - . Yang pada umumnya tetap kembali pada kata 'llama yaitu mengetahui, mengajarkan, mendidik. yang menunjukan makna pekerjaan yang berulang-ulang. Sehingga ta' ${ }^{\prime}$ im merupakan proses mengajar bekal pengetahuan yang sifatnya berulang-ulang.

c) Ta'dib

Ta'dīb berasal dari kata أدب yang berarti mendidik atau memberi adab. Sehingga dapat diartikan sebagai proses yang lebih fokus pada pembinaan akhlak.

Ketiga term di atas, dapat dikatakan bahwa pendidik yang dimaksud pada penelitian ini mengacu pada kata ta'lim berdasarkan hadis yang akan diteliti, yaitu pendidik memungkinkan berpredikat sebagai guru (di Madrasah Ibtidaiyyah al-Mubarak DDI Tobarakka, sehingga tugasnya bukan hanya memberi ilmu tetapi juga keteladanan.

\section{Peserta didik}

Peserta didik yang dimaksud dalam penelitian ini adalah anak yang masuk kategori usia tujuh sampai usia sepuluh tahun, berdasarkan hadis Nabi saw. mengenai perintah terhadap orang tua untuk mendidik anaknya melaksanakan salat ketika berumur tujuh tahun dan memberi sanksi apabila tidak melaksanakannya ketika berusia sepuluh tahun. Dalam hadis beragam lafal yang digunakan untuk kata anak, diantaranya lafal șibyan jamak dari kata șabi, aulād jamak dari kata walad, abna' jamak dari kata ibn, , yaitu sebagai berikut:

a) Term șabi bermakna anak yang masih muda usianya.

b) Term ibn bermakna anak dalam senasab

keterampilan dan kemahiran (aspek teknologi). Lihat Umar Tirtarahardja, Pengantar Pendidikan (Cet. II; Jakarta: Rineka Cipta, 2015), h. 165-166. 
c) Term walad juga berarti anak, yang tidak mesti anak kandung. Bisa saja murid.

Beberapa term di atas, menurut penulis yang paling tepat digunakan ketika berbicara mengenai perintah mendidik anak melaksanakan salat adalah term walad Hal ini dikarenakan term walad sendiri digunakan dalam redaksi hadis (مرو أولادكم) mengenai mendidik anak melaksanakan salat.

\section{B. Kualitas Hadis tentang Pendidikan Salat terhadap Anak}

Setelah melakukan penelusuran hadis yang menjadi objek kajian dengan menggunakan beberapa metode, maka peneliti menemukan hadis tersebut berada pada beberapa kitab sumber, yaitu: Sunan al-Tirmiži, kitab Sunan Abū Dāud, Sunan al-Dārimī, Musnad Ahmad bin Hambal, Mưjam al-Kabīi li al-Ṭabrāni, Mustadrak Hākim, Ibnu Khuzaimah.

Adapun hadis yang diperoleh sebagaimana yang tercantum dalam kitab Sunan al-Tirmiżi sebagai berikut:

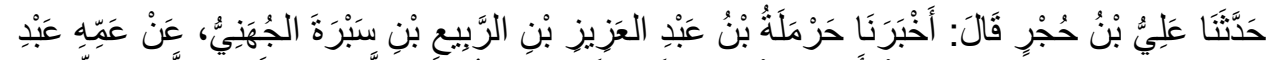

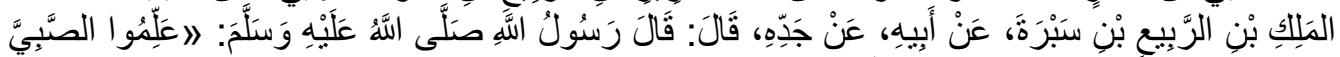

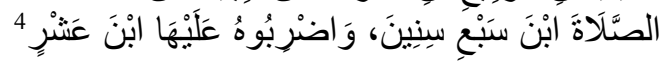

Adapun hadis yang diperoleh sebagaimana yang tercantum dalam kitab Sunan $A b \bar{u}$ Dāud sebagai berikut:

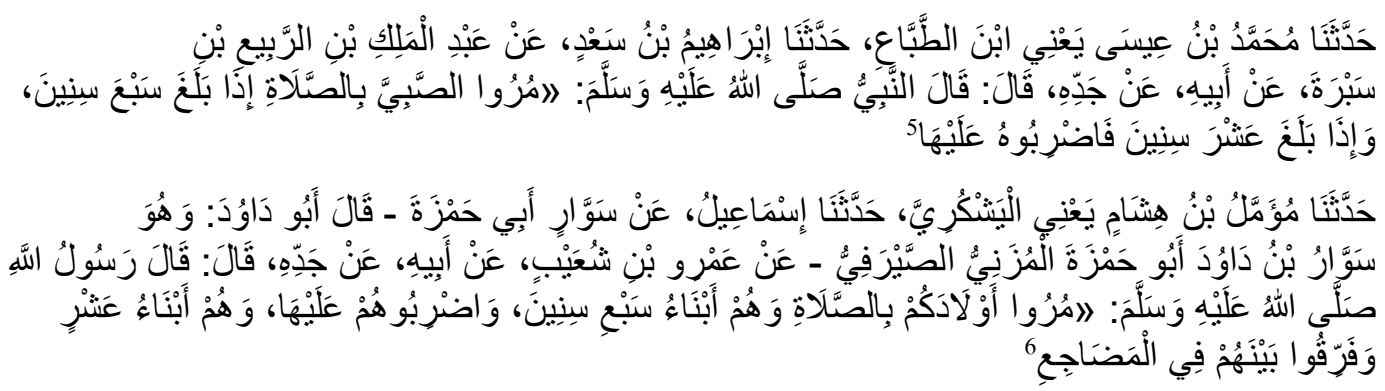

Adapun hadis yang diperoleh sebagaimana yang tercantum dalam kitab Sunan al-Dārimī sebagai berikut:

${ }^{4}$ Muḥammad Ibn 'Isā Ibn Sūrah Ibn Mūsā Ibn al-Ḍahāk al-Tirmiżī Abū 'Isā, Sunan alTirmiżīi Juz II (Cet. II; Mesir: Syirkah Maktabah wa Maṭbū' ah Muștafā, 1975), h. 259.

${ }^{5}$ Abū Dāud Sulaimān bin al-Asy'as bin Ishāq bin Basyīir bin Syaddād bin 'Amr al-Azdì al-Sijistānī, Sunan Abīi Dāud juz. I ( Beirut: Al-Maktab al-'Așriyyah, t.th), h. 133.

${ }^{6}$ Abū Dāud Sulaimān bin al-Asy'as bin Ishāq bin Basyìr bin Syaddād bin 'Amr al-Azdì al-Sijistānī, Sunan Abū Dāud, h. 133. 


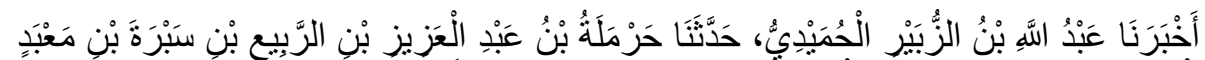

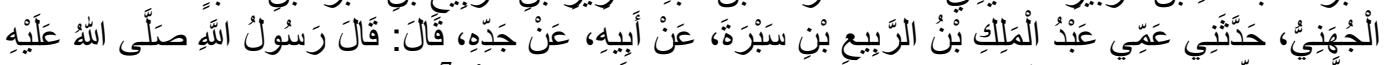

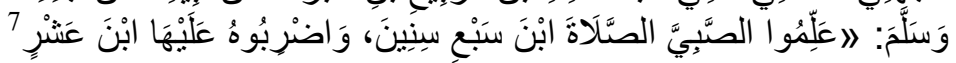

Adapun hadis yang diperoleh sebagaimana yang tercantum dalam kitab Musnad Ahmad bin Hambal sebagai berikut:

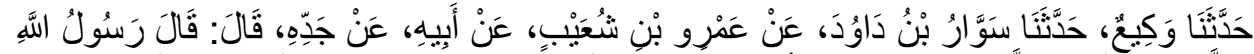

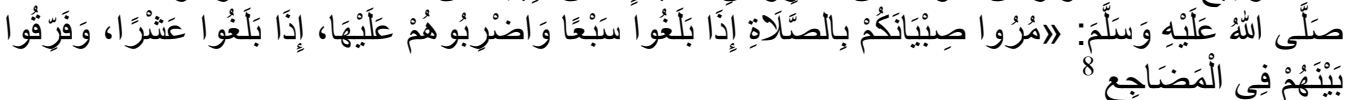

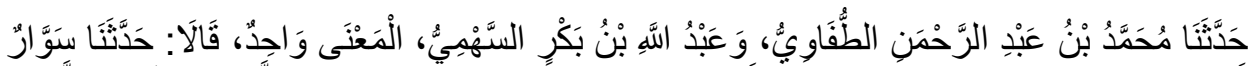

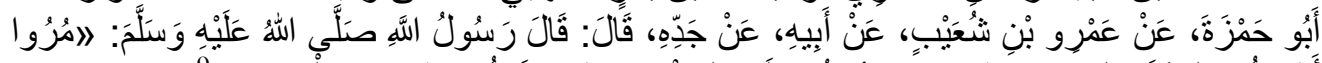

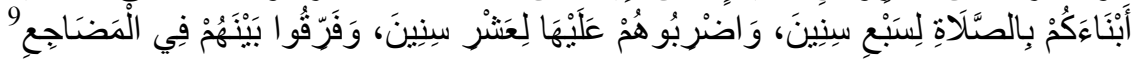

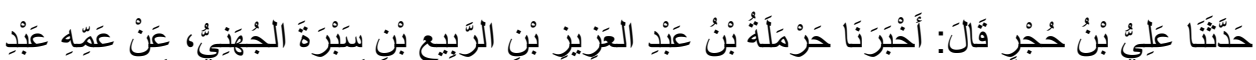

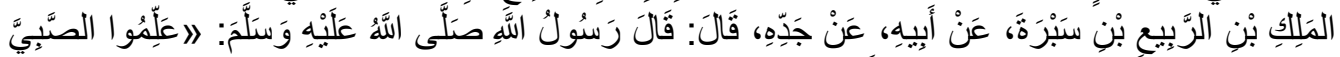

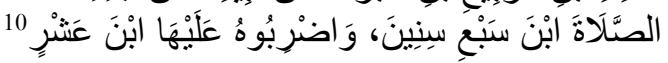

Setelah melakukan penelusuran dan pengumpulan hadis-hadis yang berkaitan dengan objek kajian penelitian, maka tahap selanjutnya dalam penelitian ini adalah melakukan i'tibar. . Dengan i'tibār, akan terlihat secara jelas nantinya seluruh jalur sanad hadis yang diteliti, demikian pula seluruh namanama periwayat dan lambang periwayatan yang termuat dalam hadis tersebut. Tidak hanya itu, yang terpenting dalam kegiatan ini adalah dapat menyingkap apakah hadis tersebut hanya diriwayatkan oleh satu orang saja atau ada pendukung lain yang berstatus syāhid dan mutābi'.

Berdasarkan hasil pencarian hadis sebelumnya, peneliti menemukan 13 jalur hadis secara keseluruhan. 7 hadis berada pada Kutub al-Tis'ah (kitab Sembilan), yaitu 2 hadis yang diriwayatkan oleh Abū Dāud dalam kitab Sunannya, 1 hadis yang diriwayatkan oleh al-Tirmizi dalam kitab Sunan-nya, 3 hadis yang diriwayatkan oleh Ahmad bin Hambal dalam kitab Musnad-nya, 1 hadis yang diriwayatkan oleh al-Dārimi dalam kitab Sunan-nya. 6 hadis yang lain berada pada beberapa kitab hadis di luar dari kitab Sembilan.

${ }^{7}$ Abū Muhammad 'Abdillah bin 'Abdirraḥman bin al-Fạ̣l bin Bahrām bin 'Abdișșamad al-Dārimì, Sunan al-Dārimi juz II (Cet. I; t.p: Dằr al-Mugnì li al-Nasyr wa al-Taizì', 2000), h. 897.

${ }^{8}$ Abū 'Abdillāh Aḥmad bin Muhammad bin Hambal bin Hilāl bin Asad al-Syaibānīi, Musnad al-Imām Ahmad bin Hambal juz. XI (Cet. I; t.t: Muassasah al-Risālah, 2001), h. 284.

${ }^{9}$ Abū 'Abdillāh Ahmad bin Muhammad bin Hambal bin Hilāl bin Asad al-Syaibānī, Musnad al-Imām Ahmad bin Hambal juz. XI, h. 369.

${ }^{10} \mathrm{Abu}$ 'Abdillāh Aḥmad bin Muḥammad bin Hambal bin Hilāl bin Asad al-Syaibānī, Musnad al-Imām Ahmad bin Hambal juz. II, h. 259. 
Dari 13 riwayat hadis tersebut, peneliti membatasi pada kitab sembilan, yaitu 7 riwayat, dari tingkatan sahabat, yaitu Sabrah dan 'Abdullāh bin 'Umar. Sedangkan pada tingkatan tabiin al-Rabi' dan Syu'aib.

Hadis tentang kapan menyuruh anak melaksanakan salat tampil menjelaskan bahwa salah satu bentuk upaya menjaga diri dan keluarga adalah dengan memerintahkan salat. Hadis tersebut mereduksi arti kata anfusakum. Hal ini karena sulitnya memerintahkan anak untuk melakukan salat jika orang tuanya sendiri tidak melakukannya. Oleh karena itu, adanya perintah terhadap anak untuk melakukan salat apabila umur tujuh tahun, secara implisit mengandung pengertian agar orangtua senantiasa memberikan contoh kebaikan (melakukan perintah agama) kepada keluarganya, termasuk anak-anak mereka. Karena tatkala anak berusia tujuh tahun itu pada dirinya tumbuh kemampuan untuk berimitasi terhadap lingkungannya. Oleh karena itu, pendidikan dan dakwah dalam suatu keluarga mesti dimulai dari orangtua sendiri.

Setelah mengadakan penelusuran pada kitab-kitab sabāb al-wurūd alhadì dan kitab syarh hadis, tidak disebutkan secara khusus yang melatarbelakangi disabdakan hadis tentang menyuruh anak untuk salat. Munculnya hadis perintah salat terhadap anak dapat diketahui ketika ada seorang sahabat yang bernama Muaż bin 'Abdillāh bin Khuaib al-Juhni bertanya kepada istrinya, "Kapankah anak-anak itu harus mengerjakan salat?" Dan istri tersebut menjawab, "Seorang di antara kami menyebutkan bahwa Rasulullah saw., bahwasanya beliau pernah ditanya seseorang tentang itu." Atau bisa dikatakan bahwa sabda Nabi saw. tentang kapan diperintahkanya salat kepada anak ketika ada seseorang yang bertanya kepada beliau tentang itu.

Mengenai umur yang menjadi pedoman dalam hadis, bahwa diperintahkan anak salat ketika umur tujuh tahun, dan dipukul ketika meninggalkan salat umur sepuluh tahun. Zaman sekarang umur tujuh tahun sudah memasuki tingkatan SD kelas satu, dan umur sepuluh tahun memasuki tingkatan SD kelas empat. Mengenai redaksi yang mengatakan pukullah, banyak ragam bentuk memukul, baik itu fisik maupun non fisik. Apabila dipahami secara teks, maka memukul dalam artian fisik. Namun, apabila dipahami secara konteks, dipukul dalam artian diberi hukuman yang bisa saja non fisik. Seperti memberi hadiah, teguran, apabila meninggalkan salat supaya anak menjadikan motivasi dan kebiasaan. Sehingga, lambat laun anak mulai terbiasa untuk salat.

\section{KESIMPULAN}

Kualitas hadis tentang perintah salat terhadap anak dinilai sahih, karena telah memenuhi kriteria syarat-syarat hadis sahih sanad dan matan. Ketersambungan periwayat dari Muammal bin Hisyām sampai Rasululullah saw., dan tidak ada pertentangan ulama dalam menilai para periwayat tersebut.

Kandungan hadis tentang perintah salat terhadap anak. Jika hadis tersebut dipahami secara tekstual, maka orang tua memerintahkan anaknya salat ketika 
umur tujuh tahun, dan apabila sudah berumur sepuluh tahun maka pukullah. Namun, memukul di sini bisa saja dipahami secara fisik. Sedangkan hadis tersebut apabila dipahami secara kontekstual dalam hal diperintahkan memukul bagi yang tidak melaksanakannya, maka harus diperhatikan terlebih dahulu. Memukul anak secara fisik, dalam konteks sekarang sudah ada aturan undangundang perlindungan anak. Sehingga memberikan hukuman yang sifatnya non fisik. Adapun hadis tersebut secara intertekstual, telah disebutkan dalam alQur'an bahwa orang-orang mukmin agar mendidik diri dan keluarganya. Dalam hal ini orang tua mengajarkan salat kepada anaknya. Dan hadis tersebut bersifat universal, berlaku pada semua tempat, zaman dulu sampai sekarang

\section{DAFTAR PUSTAKA}

āl bin Asad al-Syaibānī, Musnad al-Imām Aḥmad bin Hambal juz. XI.

Abū 'Abdillāh Ahmad bin Muhammad bin Hambal bin Hilāl bin Asad alSyaibāni, Musnad al-Imäm Aḥmad bin Hambal juz. XI (Cet. I; t.t: Muassasah al-Risālah, 2001).

Abū Dāud Sulaimān bin al-Asy'as bin Ishāa bin Basyīr bin Syaddād bin 'Amr alAzdì al-Sijistānì, Sunan Abū Dāud.

Abū Muhammad 'Abdillah bin 'Abdirrahman bin al-Faḍl bin Bahrām bin 'Abdișșamad al-Dārimi, Sunan al-Därimi juz II (Cet. I; t.p: Dār al-Mugni li al-Násyr wa al-Taizi', 2000).

Muhammad Ibn 'Isā Ibn Sūrah Ibn Mūsā Ibn al-Dahạ̄k al-Tirmiżi Abū 'Isā, Sunan al-Tirmiżi, Juz II (Cet. II; Mesir: Syirkah Maktabah wa Maṭbù ah Mușțafā, 1975).

Republik Indonesia, "Undang-Undang RI Nomor 20 Tahun 2003 tentang Sistem Pendidikan Nasional" (Cet. II; Bandung: Citra Umbara, 2010).

Tim Pustaka Phoenix, Kamus Besar Bahasa Indonesia, Edisi Baru. 